\title{
Round Table: What Is Happening in the Islamic World? An Attempt at a Conceptualization
}

DOI: $10.22394 / 2311-3448-2018-5-1-107-138$

This round table addressed the question of research methodologies for those trends now observable in the Islamic world, as well as conceptual approaches for understanding current developments there. Such frameworks as Islamic reformation, a neomodern age, and the search for a political Islamic identity were proposed. Participants did not agree about the relationship between Islamic fundamentalism and modernity. Some of them considered fundamentalism as potentially a modernist movement, and others saw it only as antimodernist and archaic. In this respect, they raised the question of balance between declared goals and real impact on social development - in other words, can those groups that call for a return to the past actually facilitate movement forward? The participants paid particular attention to terminology. They also actively discussed the issue of language for scientific analysis and the language that different Islamic movements used to present themselves, and whether they were necessarily interconnected or could be fully autonomous.

Keywords: Islam, Islamic world, Islamism, Martin Luther, fundamentalism, Reformation, modernity.

Participants in the round table: Irina Starodubrovskaya (Gaidar Institute for Economic Policy), Orkhan Jemal (1966-2018, journalist), Emil Pain (Higher School of Economics), Vasily Kuznetsov (Institute of Oriental Studies of the Russian Academy of Sciences), Dmitry Uzlaner (Russian Presidential Academy of National Economy and Public Administration), Akhmet Yarlykapov (MGIMO-University).

Originally published in Russian as: "Kruglyj stol: Chto proiskhodit v sovremennom islamskom mire: popytka konceptualizacii (Irina Starodubrovskaya, Orkhan Jemal, Emil Pain, Vasily Kuznetsov, Dmitry Uzlaner, Akhmet Yarlykapov)” (2017), Gosudarstvo, religiia, tserkov'v Rossii i za rubezhom 35(3): 265-299. 
Irina Starodubrovskaya: Respected colleagues, we have all noticed that there is now a heightened interest in the Islamic world. Something is clearly happening there. There are such processes occurring as religious renewal, increased conflict, and a sharp rise in the political role of fundamentalist views, which call for a return to the sources and a rebirth of the Islamic caliphate. We have gathered here to discuss how to analyze these processes and what kind of conceptual framework would most suitably allow us to understand their essence and perspectives. This round table is dedicated to this fundamental problem. With your permission I will start our discussion.

I would like to discuss Islamic fundamentalism and modernity. At the same time, I will not dwell on whether it is worthwhile to examine these problems in the framework of large narratives. Yes, when we speak of Islamic fundamentalism, when we speak of modernity, we can always say that these are constructs, which do not have clear-cut, real meanings, and it is not worthwhile to work with them. This is a topic that we can discuss, but I do not want to start with it, because we can stray far from the topic of our discussion.

So, I will talk about how Islamic fundamentalism relates to modernity. In order to speak on this topic, we first of all need to define what modernity is, rather than what Islamic fundamentalism is. Because here we can identify two principally different interpretations. One of these interpretations is linear. The era of modernity is an era of progress, a movement away from the accursed past to a bright future. Within this framework, the system of values worked out during the Enlightenment is increasingly realized. This is a very pretty model, but it has one problem. It does not at all correspond to reality. Because, if we look at the modern era as it truly was, we see that it was a series of crises. Starting with the crisis of early modernity, with its urbanization, workhouses, monstrous overcrowding in cities, and repressive laws against vagrancy. Further, the light of the Enlightenment era ended quite quickly, even if we are prepared to consider the guillotine on the Place de Grève as light. The economy is changing, the era of coal and steel is beginning, as is the active monopolization of production. Instead of competition, we see regulation by large economic agents both of economic and all other life, and interaction with the state on that basis. The Enlightenment idea of the limitless strengthening of rationalism and the submission of nature transforms into the idea of the unlimited strengthening of rational or non-rational control of the state, about which Michel Foucault clearly wrote, that institutions of forced detention, insane asylums, and pris- 
ons resembled barracks, factories, schools, which in their turn resembled insane asylums and prisons. Later, after the Second World War, for a while the ideas of modernization as a prescription for all of humankind flourished, and then the 6os begin, which are in essence a crisis of High Modernity, the ideology of which was formed in the preceding period.

Finally, we can characterize the existing situation as a kind of challenge of globalization, as some sort of crisis of globalization. The essence of this crisis it that the world has become very small. The world has become very connected by transportation, and we are forced to live alongside cultural strangers. Not simply alongside a person whom we do not personally know, as it was, for example, in the era of urbanization as described by the founders of sociology, but with people who have a different manner of life, different values, different norms. And now is the period in which we learn to live with these cultural strangers. However, for now we are not learning very successfully.

If we are going to speak of modernity as a series of crises, then we might attempt to look at the Islamic revival, which is connected to a rather widespread dissemination of fundamentalist ideas, as the search for an answer to a crisis situation. Because here the situation has turned out to be rather complicated. In essence, several crises have coincided. In many countries, the crisis of early modernization, associated with intense urbanization and an erosion of traditional society, has coincided or almost coincided with the crisis of High Modernity. And if we perceive the era of modernity not as a smooth movement along a previously established arc, but as a search for answers to ever newer challenges, a search often in the dark, a search often by blind touch, then it seems to me fully possible and legitimate to look at the events in the Islamic world as one of the directions of this search. This is actually the first idea I want to tell you about. And now concerning Islamic fundamentalism. This movement goes by different names; some call it Wahhabism, Salafism, or Islamism. Unfortunately, the terminology has not been definitively settled. I will call it either Islamic fundamentalism or nontraditional Islam, as the widest generalized understanding, which in one way or another includes all the others. Ideas about this movement are also very frequently simplistic: that it is a certain type of united movement based on a single ideology, upholding united principles and rejecting modernization as a direction of development. I think that if we try to look at it outside of the fears, myths, stereotypes with which it is often associated, we will see the following picture. 
First, large groups of people begin to consider the world in religious categories independently and in various ways. They themselves read the primary sources, and themselves try to make sense of these issues. For them religion becomes not simply a collection of ceremonies and rituals, but an instrument for understanding their surrounding reality. The second thing we see is that people strive to change their lives in accordance with the norms prescribed in religion. Third, in fact, under the slogan of returning to the sources, people have set themselves far apart not only from Western models, but from established traditions. This point is very often interpreted incorrectly: it is believed that a return to the sources is a return to traditions. As I understand it, this is far from the case. When we talk about sources we must understand which sources are being discussed. We are talking about the period of a religion's emergence, the charismatic period, the heroic period, the period when existing structures and attitudes were fractured, when a new ideology won adherents. That is, we are speaking of a period of very active disruption. And then this new ideology adjusts to the rituals of everyday life, to the existing system of interests, to normal practices. Therefore, in reality, a return to the sources is not at all a return to tradition. In many ways it is a rejection of tradition. Furthermore, we see that in all of this there is a good deal of violence. This is the violence of those who try to force others to live by norms that they see as correct, while those others either do not want to or do not know how to live by these norms. This is the violence of adherents of different variants of Islamic ideology in relation to each other. That is, in reality, the environment is imbued with conflicts, opposition, and violence.

Well, essentially, when I enumerate all this evidence we get a picture of the Protestant Reformation, practically in one-to-one correspondence. This is where the idea of the Islamic reformation came from. In fact, from my point of view, this method of evaluating the consequences of the Reformation, which developed in scholarship thanks to Max Weber and other researchers of the modernizing potential of the Reformation, applies very well to the current situation in Islam. Because on the one hand, the reforming, modernizing effect is tied exactly to the destruction of traditional norms and attitudes. That is, it clears the field for something new. Until it is cleared, it is hardly possible to speak of any kind of serious changes. Further, certain values that are proclaimed by fundamentalist Islamic currents carry a truly modernizing character. If in the Reformation the values of conscientious labor were primary, then here it is possible to talk of the 
values of education, which are raised up by some in this movement. Here we can speak about the values of a healthy lifestyle, completely contemporary and modern. Here is it possible to speak of the values of the conscientious fulfillment of agreements, and also of other openly modernizing values.

But it seems to me that it is much more interesting in this context to talk about the phenomenon that Max Weber wrote about. His approach, which suggests that certain modernizing values were formed not because of Protestant ideology, but as an unforeseeable and often undesirable consequence of the implementation of certain religious norms, is most interesting. Here the situation is also rather similar. We can talk, for example, about the values of individualism. Again, it is approximately the same as in the Reformation era; people themselves choose their own religious leanings and have the possibility of choice. They do this not because they are embedded in a traditional hierarchy, generational hierarchies, or hierarchies of seniority. They do this directly due to individual decisions. A horizontal community of likeminded people becomes in many situations more important than vertical hierarchies. And essentially in its purer form the ideology suggests that a person should submit to the Almighty and not to other people.

We can talk about education of the law-abiding, so far as the unconditional fulfillment of Shariah law is included in this ideology. An elder or head of a clan cannot determine either the structure of a crime or misdeed or the punishment in this system; only a judge can, by clearcut, fixed laws. Well, again, we can talk at length about which modernizing values are indirectly formed in this manner. At the same time, in this movement we can see many anti-modernizing values. And, besides this, it is in far from all situations that similar religious schisms are connected with a modernizing agenda, as traditional conflicts between clans, tribes, villages, etc., quite often completely mimic themselves under this religious framework. That is, we have a similar, often complicated, ambiguous picture.

I would say that the result is actually unpredictable, just as the result of the Reformation was in general unpredictable. Because it is unlikely that when Cromwell's "saints" cut off the English king's head anyone would have imagined that England would be the leading industrial power for a long time. Or could anyone imagine when the Protestants immigrated to America in order to build a "city on a hill," practically the kingdom of God on earth, that the United States would be the most advanced democratic government, the first to include the 
separation of church and state in the Constitution. In fact, my idea is that the process is very complicated and ambiguous. It's impossible to consider it either as unambiguously modernizing or as unambiguously antimodernizing. And it is important to understand how very different processes, very different ideologies, very different groups in reality coexist in the framework of this seemingly united movement or united process and understand how all this can influence the final result in various ways. I will finish with that. Does anyone have questions or commentary?

VASILY KUZNETSOv: I completely agree with the last paragraph of all you have said.

IRINA STARODUbrovsaia: Is that the only thing that you agree with?

VAsily Kuznetsov: No, not the only thing. I'll try to present two perspectives. I have two ideas about how to conceptualize and analyze the current processes. I will not use the term "Islamic world"; I do not like it. I also do not like the term "Islamic fundamentalism." For many reasons, it seems to me that it is not correct. We can still argue over "Islamic world," but as for "Islamic fundamentalism," I never really understand what that is.

One perspective that I suggest is tied directly to the understanding of modernity. It seems to me that we can look at the era of modernity, proposing it as having at least two chronologies. We can speak of a brief modernity, beginning, let's say, with the French Revolution, more or less. We can also speak of a long modernity, which, it appears, began with three important things: with Gutenberg, with firearms, and with Cogito ergo sum (I think; therefore I am). These three things formed the Western world and modern civilization. The principal thing here is that the printing press and firearms allowed the creation of a stable hierarchy: a stable hierarchy of power and a stable hierarchy of knowledge - more stable than they had been to this point. They allowed the creation of contemporary society and contemporary institutionalized state, a government of institutions.

The modern era, as it seems to me, ends with the famous phrase, "There can be no poetry after Auschwitz."

After this the postmodern era begins and the erosion of all these ideas of progress, development, and the unending movement toward the better. We all know this well. And of course this process involves not just culture, not just architecture, literature, or philosophy. It also 
affects international relations; it affects politics. Those regimes that were overturned in the Middle East in 2011 were absolutely postmodern regimes, with a rejection of the ideologies, with an absolute rejection of the idea of some kind of truth and of development. On the whole, no one spoke of the rights of people more often than Hosni Mubarak and Ben Ali. It was in each of their speeches. Gaddafi is an excellent example: the Third World Theory explains everything and forever, including the implementation of the principles of new liberalism in economics.

However, what is more important is, of course, the crisis of postmodernity, which in the Near East was defined by the events of 2011, and all that happened after that. This crisis was far from being just Near Eastern; this crisis, I think, is much broader. Postmodernism in this manner became the highest stage in the rejection of the era of modernity, and it ends with us transitioning from the books of Gutenberg to a more or less absolute kind of informational communism. Also, the monopoly of firearms has stopped being a guarantee of the stability of the state. Changes to the essence of government structures have begun. And it seems to me, that this transition - someone has suggested naming this new era neomodernism - will be a long time starting. In the first stage it has the signs of a crisis of globalization. But "crisis of globalization" is a stupid expression, because globalization is a kind of objective process, which is connected with the scientific and technical development of humanity. There are some people, some societal forces, that do not like this. People who have not seen migrants in real life voted for Trump and his migration policies. People who have not seen Muslims in real life voted for Brexit. What could they have seen, sitting in English villages? It is a fear of the future, and it is a natural fear.

It seems to me that two trends that are observed today are important in this approach to neomodernism. The first is the rise of demands for new expression, for the creation of some kind of new narrative, because postmodernism led to the rejection of any sort of strategy of development, a rejection of the future. There was no perspective of development, no conception of what we wanted. Now the demand for some conception exists, but this demand appears often in archaic forms. It is connected with a return to some sort of more or less untamed form of social relations, to xenophobia and so on and so forth. We can consider this archaism as the second trend. It seems to me that turning to antiquity in the search for new expression can be explained by the fact that the information stage is in fact the stage of political explosion, of a rapid widening of the political space, when the 
dictates of the former elite become impossible. As a result, being invariably archaic, the new message assumes different forms - the most radical being Daesh ${ }^{1}$ and the less radical Trump. But in general, these are all things of the same order. This is the first idea of which I wanted to speak, and it is not connected directly with Islam.

The second perspective is essentially Islamic. When the prophet Muhammad came with his Message, he proposed a definite conception of a historical worldview. This conception principally differed from the Judeo-Christian in that it presupposes cyclic recurrence. There are prophets who periodically arrive, then these prophets die, the community gets off track, the next prophet arrives and so forth. And each Ummah has its own prophet, right? In this manner the world develops along a sine curve that presupposes cyclic recurrence. As a whole, I think that in connection with this idea, modernization through a return to the sources, through Salafism, is to a large degree more characteristic of Islam than of the Judeo-Christian tradition. In general, the history of Islam can be described as the history of Salafism. Each or almost every empire that has arisen in the Near East began with someone who came and called for a return to the true purity of faith, cleansed of bid'a (negative innovation). How this purity of faith is understood is a different question.

Islamic renewal, of course, began not in the 20th century, but in the 19th, when the problem of the clash with colonialism arose. Then the problem arose that if we have the true religion and we are the most admirable, why do we suffer defeat all the time? And we know that very different answers were given to this. Some said that the problem was in Islam, that is another line. We should not forget that it exists. Atheistic, or at least radical secular ideas, are very widespread. It was so and is still. Also, there was the Salafism issue. When we speak of Salafism, the question is to which true purity of faith are we returning; what exactly lies at the base of this purity? Of course, it is a reconstruction of the past. Of course, this is not a return to tradition, but a breaking of tradition. The question is, a breaking in the name of what? In general, what we today call Euro-Islam, is also Salafism. Because that is also a call to return to true purity, because true Islam and the essence of early Islam is ijtihad, is dynamic, is openness. This is why I do not like the term "fundamentalism."

1. Forbidden in the Russian Federation by the decision of the Supreme Court of the Russian Federation on 12/19/2014, № AKPI 14-1424C. 
Emil Pain: And what should be used in place of it? Salafism? Simply to understand.

VASily KuZnetsov: We can say "Salafism," but we must always understand what we are talking about. I am not completely sure that we can generalize these movements. I am not completely sure that it is possible today to conceptualize it. There is the idea that we also need to reject the term "Salafism" because in the final analysis we understand completely various things as the Salafist movement. You have Muhammad Abduh the Salafi and so-called Caliph al-Baghdadi the Salafi, after all.

Irina Starodubrovskaya: At that you have "Hizb ut-Tahrir" ${ }^{2}$ and the "Muslim Brotherhood," 3 which are also Salafi, but do not always consider themselves to be Salafi.

VAsily Kuznetsov: And so, when we speak about Islamic societies, we first have the general modernization process, which we talked about. We have the crisis of the state system associated with archaization. These are all things that in my opinion have no relationship of any kind to Islam. Also, violence has no relationship to Islam in the given situation. This is not because I want to be politically correct. I truly think so. Fifty years ago, that same violence occurred under socialist or nationalist slogans, and in twenty years it will be under some other kind of slogans. It is a question of time. However, the process of ideological seeking exists in the framework of a single Islamic intellectual space. It absolutely exists. To what extent does this process correspond to social reality? It is far from linear and far from always corresponds with it. To return to what I began. Why don't I like the term “Islamic world?” Because the Islamic world is also some kind of fantasy of ours.

It exists more than anything in the heads of Muslim immigrant societies in Europe and it exists among Muslim minorities. This identity is very strong there. However, go to any Muslim country. What quantity of liberals or atheists, let's say, are in Saudi Arabia? I don't know, you understand. What percent of people do not observe Ramadan? Are people who do not observe Ramadan or believe in Allah part of the

2. Forbidden in the Russian Federation by the decision of the Supreme Court of the Russian Federation of 2/14/2003 № GKPI 03 116, which went into effect 3/4/2003.

3. Forbidden in the Russian Federation by the decision of the Supreme Court of the Russian Federation of 2/14/2003 № GKPI 03 116, which went into effect 3/4/2003. 
Islamic world? I do not know; I do not have an answer to that question. Well, I could also give other examples. Probably I will stop with that.

ORKHAN JEMAL: I have some questions. First, what do we mean by the combination of words "Islamic world," the existence of which you deny? Because coming from your context, and from what you have said, by the Islamic world you imply some kind of commonality with which no one would identify themselves. While it is completely obvious that the Islamic word is an absolutely real, objective thing. You would not deny the existence of the Christian world, which has with time evolved in the Western understanding. If we speak of the Islamic world, specifically about the Islamic world as a geographic concept, then even here political agency has had a place for a very long time. The caliphate has existed in various forms, both as a global entity and as a more local, regional entity. Thus, the Islamic world is absolutely at a minimum a historical reality.

Second, I simply want to draw your attention to the idea of incongruity between fundamentalism and Salafism. This is also a rather conditional thing. As Martin Heidegger wrote, in no term is there more content than in the sense of the words from which it is composed. In actual fact, Salafism comes from al-salaf al-șālih, a return to the righteous forbearers. It is a restoration of the fundaments, which is exactly what fundamentalism is. Another thing is that in Salafism there is a certain hint of politicized content, in contrast to Islamic fundamentalism. Islamic fundamentalism can contain the archaic, that is, opposition to bida. When we speak of Salafism, let us remember that in principle it is, of course, Islamic fundamentalism. It was realized and manifested, however, as a protest ideology, appearing as a response to an outside threat. Starting with Ibn Taymiyyah who opposed the Hulaguids on ideological terms, and Ibn Abd al-Wahhab, who opposed Turkish hegemony in the Hijaz. We can talk of contemporary Salafism or Ikhwan ${ }^{4}$ Salafism of the 2oth century, which also is a reaction to the outcome of WWI. And in this sense, of course, Salafism is Islamic fundamentalism, which has some political-protest connotations. I am simply drawing your attention to the fact that that term is absolutely correct.

VASILY KuZNETSOv: Thank you. Concerning the Islamic world, why is it that I do not like that concept, why do I try not to use it, when we are speaking of modernity? I think we can talk about three foundations of

4. The word "Ikhwan" means brotherhood and refers to al-Ikhwān al-Muslimūn (the Muslim Brotherhood). 
the "Islamic world." About the existence of some idea of Dar al-Islam in both the political and intellectual tradition. About identity, above all about the deterritoralizing community of Muslims, about which Olivier Roy wrote. And the third thing we're talking about, and which I think is the most important, is the image that is formed by the West in seminars such as ours and in larger forums as well. I think that when we analyze reality, the Islamic world does not form a unified geographic expanse from Indonesia to Senegal. These are completely different societies. There is no single political space. Despite the existence of the Organization of Islamic Cooperation, there have been more wars between Muslim countries within the Islamic world in the 20th century than there have been between anyone else. There is no joint economy nor joint economic system. And if we are going to talk not only about governmental agency, but also about societies, then I think within a considerable part of these societies religious identity is not a deciding factor. For a sizeable portion of the population, religious identity does not play a principal role. It is not key. Thus, I do not like the term "Islamic world," because it generalizes completely different things on a basis that is not very understandable, and very broad conclusions are drawn from this. Yes, it is possible to use it in some limited discursive practices.

Concerning fundamentalism, it is of course a direct translation both fundamentalism and Salafism. As a rule, when we speak about Islamic fundamentalism, frequently it does not only involve the understanding of some ideological currents. If we confine ourselves to the fact that it is a method of thinking, then yes. But if we start to compare it with Christian fundamentalism on the one hand and on the other hand with contemporary sociopolitical practices, then we fall into the trap of analogies. This allows us to equate the contemporary Near East and medieval Europe. In order to avoid this temptation, it is better to abandon the term fundamentalism.

Orkhan Jemal: But Ms. Starodubrovskaya has tried to apply the Christian understanding of fundamentalism to Islam and has come to the conclusion that it is very similar to the Protestant Reformation. Because Luther nailing the 95 theses to the door of the cathedral is fundamentalism in a pure form, in a refined form, without the least admixture.

VASILY KuZnetsov: You cannot argue with that.

Irina STARodubrovskaya: I have one question for Vasily, regarding cyclicity and the return in every cycle to some new variant of fun- 
damentalism or puritanism. In reality, in scholarship there are two points of view that I know of on this subject. One is that since everything goes around in a circle, then in essence nothing changes. That is, the cycle continues: there are fundamentalists, then everyone returns to folk beliefs, then in the next cycle fundamentalist ideas arise, they again come down to the level of folk prejudices and conceptions, and so on. This is one position. Another position: everything was roughly this way, while society was sufficiently traditional. Then urbanization begins and city dwellers see the attractiveness of fundamentalist ideas not only as elitist ideas but as ideas sufficiently popular for a city. This creates several preconditions so that fundamentalism can lay new foundations, which then might or might not grow into modernization. Ernest Gellner as a matter of fact wrote quite a lot about this. What is this really? How do you imagine this?

Vasily Kuznetsov: The first version seems closer to me. Concerning urbanization: the process of urbanization in the Middle East and the process of urbanization in Europe were fundamentally different. In the Middle East, there was not the factor of the growth of cities, which in Europe occurred since the thirteenth century with their particular status. Islam itself was originally an urban culture. How did the Arab peasantry live in any century? God only knows. There are no sources by which it is possible to speak normally of the way of life of the peasantry. Or, at the least, their sphere was extremely limited. All that we call Islamic culture is urban culture, if we are talking about the Middle East. Probably in Southeast Asia, where the situation was in principle entirely different, it is somehow different, I really do not know. Therefore, it seems to me that this is an antithesis: of the contemporary and traditional city. The antithesis is largely removed here, because all the processes occurred in cities. And Salafism was in cities.

Irina Starodubrovskaya: Well, probably, we will not go into details now, because we would have to discuss in great detail the difference between traditional cities and contemporary cities, between the phenomenon of the city and the big city. Who is next? Orkhan?

ORKHAN JEMAL: I would now like to turn our attention to the historic circumstances in which present-day Islamism formed. I will use that term and for a start I will define what it means. Political Islam is called Islamism. It is a religious doctrine that demands embodiment through sociopolitical methods and demands submission of so- 
ciopolitical education to some general religious principles. This is not a unique situation, because even in the 2oth century in the context of a more decrepit Christianity similar rather specific movements appeared - liberation theology in Latin America, the Catholic-Protestant parties in Germany, the system of varying types of concordats between the Vatican and governments, between the Georgian Orthodox Church and governments. That is, it did not arise only in Islam.

Vasily Kuznetsov: Can you elaborate?

ORKhan JEMAL: Yes.

VASILY KuzNETSOv: But is Islamism a religious movement?

ORKHAN JEMAL: It is a religious movement that demands the implementation of its ideas in the political sphere. Moreover, the entire body of politics is implied, including both outside agreements that must be submitted to these principles, and internal ones. You spoke of how goal-setting was lost in regimes that split at the seams in 2011. But this here is just goal-setting. It is countercyclical by its nature, since Islam is all the same an eschatological religion. The prophet came, namely in order to cut short cyclic recurrence.

Now let's analyze the context in which Islamism appeared: the 19th century, the era of modernity. This is the last century in which the caliphate still existed. From the time of the arrival of Islam for one and a half millennia most centuries passed under a caliphate or various caliphates, but there has always been some kind of agency. Moreover, the Abbasid caliphate was perhaps one of the most successful examples of medieval globalism in the world. Globalist European modernism received some antecedents when eastern globalism was exhausted. The discovery of America had already begun, the change of trade routes, the industrial revolution, etc. However, until the beginning of the 2oth century the world lived under the caliphate, that is there always was a caliphate in the world. Under the caliphate, the times were wonderful, heroic; there was expansion. There was a period of terrible decline, when Ottoman Turkey was spoken of as of the sick man of Europe. They dreamed of when all this would finally end, when this nightmare would be over.

But just as soon as it all ended, after ten to fifteen years, a thirst for a caliphate renaissance began to arise. Approaching the 1930s, the Eastern world was a collapsed caliphate, a collapsed Islamic world. 
The structure of this territory had suffered, due to European oversight. In various eras this oversight took various forms: there was the period of monarchies, the period of mandated territories, the period of national-socialist regimes. But in any case, it was not a completely internal decision about the structure. In the best case it was a compromise between the will of the local and outside players. This was not immediate: a compromise began to appear in the 1950s. This enslaved territory experienced a state that was in general similar to that of Europeans of the 1950 s and 1960s. Such a peculiar Gaullism. It's impossible to say whether it was good under the Turks, but it's bad now.

It is interesting that Islamism appeared in Egypt. I define it as an ideology, based on Ikhwan ideas. Egypt did not suffer defeat during the First World War, but it was one of the first Islamic governments to face the problem of modernization on the European model. Moreover, not with that modernization, which we understand firstly as scientific-technological progress, but namely with geopolitical modernization, when Egypt began to be used as a springboard for the suppression of Sudanese protest movements and for pressuring Ethiopia. Behind Islamism as a movement, as an ideology, is longing for the restoration of political agency to Muslims, which, as much as you would like to deny it, still exists. It is precisely this that sits at the base of a whole layer of these political ideas.

It is necessary to note what happened later. This ideology has an extreme form and a mild form. On the one hand, a portion of the people cannot free themselves from old stereotypes: we need a government in which a caliph will rule; he will have a vizier, naibs, deputies, satraps, and all the like. On the other hand, there are other frameworks that are essentially of the same nature. Here they conceive of agency not in the terms of an archaic government, such as the caliphate. There are a decent number of radical anarchist network designs. Al-Qaeda ${ }^{5}$ exists, which depends not on top-down administrative management, but on Jamaat networks, in certain framework agreements with each other. That is, the question of what kind of restored agency there should be is still hanging in the air. It does not have an answer. At the current time it has not been completely worked out.

Now, the wonderful comparison with Protestants, which is in its own way paradoxical, in its own way provocative, has a very interesting aspect. The radicals, the Protestants fled from their English king, from their Spanish Catholics from the Netherlands. They fled

5. Forbidden in the territory of the Russian Federation. 
to America. They took some land from the Native Americans, apparently in the first periods not through much conflict, or not always through conflict. In this respect America was long an outlet for religious minorities. Until it all ended. Toward the end of the 19th century America was over and the very idea of escapism, including religious escapism, began to experience a crisis. The whole background of Russian cosmism and science fiction: gardens on Mars, it is all humankind's psychological reaction to the end of America. There is nowhere else to go. It is impossible to escape; we are in a cage. And this longing for an escape has broken forth in a portion of the people in just this way.

The Islamic world is experiencing a similar process, just in a different age and under different circumstances. Muslims also decided to run away to their America and wrest from the Native Americans their piece of land. But when we try to find a place for Islamic government in the political scale, I do not presume to place it alongside America. I do not presume, although I believe that 17th century America was a rather dark and scary government. I'll remind you that it was only in Spain that they burned people longer than in America. I would sooner draw a parallel with Marxism, and in the framework of the Marxist project with Cambodia and Kampuchea. Not the United States, not the Soviet Union, not China, not Vietnam, not Cuba, but namely with Kampuchea. In this respect I would like to note that the parallel itself, like all parallels, is imperfect, but it is a good approach as a method of research and study. In other words, look at how it happened for others in slightly different circumstances, all the while taking into account that the supporting cast is different, and that overall comparisons have their limits.

Another thing. I want to note that present-day Salafism, presentday Islamism (Salafism I would all the same allocate to the religious sphere) is longing; it is a reaction to the loss of Islamic agency. It is psychologically comparable to the yearning of the British over their empire: yearning over something large, important, and meaningful, but lost. Of course, this is the process of modernization, but not modernization in the sense of progress. It is a modernizing process, because this area is in search of new political and social technologies, new political and social relations.

Finally, when we turn away from large narratives, upon leaving them all the conversations lead to the question: what is to be done? We should give someone advice: you act thusly, and everything will be good for you. We regard this process as if some mistakes were 
made that led to this situation and they simply need to be corrected and then all will resolve. No, it will not resolve. What we call Islamism as an ideology; what we call Salafism as politicized theological viewpoints; what we call jihadism, which at essence is the armed wing of this phenomena; are certain macrohistorical phenomena, which are the consequence of other macrohistorical phenomena. They are a menacing act of history that it is impossible to correct or rectify. Perhaps it can change, as, say, Marxism played out. But just as Marxism defined the end of the 19th and 2oth centuries, so will Islamism define the 21st century. Perhaps this will change, evolve somehow.

I think that we can only talk about the long game through an analogy with Bolshevism. The Soviet Union was founded by some rather radical guys: Lenin, Trotsky. They saw the territory of the Russian Empire as a base, a foothold, that could be sacrificed. Thus, they played at revolution in Germany, at revolution in Britain, at revolution in France, since there was a proletariat there and industry as well. They were not fighting for those guys from the forest villages, whom Vladimir Ilyich himself called the petty bourgeoisie. However, in 1927 the United States recognized the Soviet Union. The concept of a permanent revolution was replaced by the concept of building socialism in one country. Then there was a peaceful coexistence of systems, a convergence. Well, then later there was Gorbachev and the well-known end.

VAsily Kuznetsov: I have some commentary. I would like to call Orkhan's attention to a few things. Speaking of the Islamic world, the geographic area of your tale was limited by Iraq on the east and Egypt, or possibly Libya, on the west. All the others had no relationship with the Ottoman Empire at the time of the war, therefore nothing was said about either Indonesia, or India, or Pakistan. That is the first thing. Second thing. This is not an objection, but simply a consideration. I do not argue when you say that political Islam is a religious movement, but then we need to analyze it as religious, and not as a political movement going forward. Third, it seems very important to me that, let's say, when we speak of the rise of the "Muslim Brotherhood" in Egypt, that it was an answer not only to the West, but also to the elite that betrayed the people. There was an element of struggle (this is also the case in Daesh), and an element of struggle against internal colonial forces, which are perceived as agents of the West. And finally, when we speak of the present-day process, when you juxtapose Islamism and Marxism, it seems to me that there is one impor- 
tant thing: due to its genetic peculiarities, the effect of the influence of Islamism is limited culturally, religiously, etc. It does not possess a universal form.

ORKHAN JEMAL: That is a very valuable observation, though I would like to remark that Marxism also has religious roots and they are namely Protestant. It is a distinct tradition of Christian utopianism. It is not Jewish utopianism. Therefore, it is not obvious that it is imperative to strictly differentiate religious and political movements. Perhaps there is not such an impenetrable barrier between them. Also, concerning what you said about limitedness, yes, absolutely. Until Islamism promotes a separate program for non-Muslims, it is doomed.

Irina Starodubrovskaya: Only the apostle Paul is missing.

VASily Kuznetsov: It seems to me that when we speak of the immeasurable yearning of Muslims for the caliphate, that it is very beautiful. It is very poetic. It is wonderful. But who has measured immeasurable yearning?

Orkhan Dzhemal: Well you know, there is immeasurable yearning for the vanished Soviet Union. Somebody has immeasurable yearning for Kipling.

IRINA StARodubrovskaya: I have the feeling that this yearning is actualized when it resonates with something personal. If nothing works out, if we cannot move forward, if our career does not work out and in general everything is bad and we have no money, and all this is because we are oppressed and we have no political agency, it is an understandable story.

ORKHAN JEMAL: I will simply draw your attention to the fact that the leaders of this movement, moreover the leaders including the midlevel, that is not just the highest ranks, are in general rather successful people.

Well, and as to the Islamic world, I say that it is difficult to deny the existence of and a certain homogeneity in Islamism. It is impossible to understand while denying, like you, Vasily, the category of the Islamic world, even if this category is theoretical. Even if some bumpkin says "Huh?" at the phrase "Islamic world." It is not the bumpkins who determine it. 
VASILY KuZnetsov: When I said that I will not use the category "Islamic world," it was of course to be provocative. It obviously worked. But the idea was that I did not want to combine that whole vast region in a social or political analysis. I already said that it is united in the minds of a significant portion of Muslims.

AKhmet YARlYkapov: I simply have a couple of things. I would really like to turn your attention to what was said regarding ideological searches in the Islamic intellectual community. It seems to me that it is completely impossible to manage without analysis of what Kemper called Islamic discourses. This Islamic discourse and all these ideological searches in the Islamic intellectual community are in my opinion very, very important. Moreover, in the 19th century all the discussions were conducted in Arabic by the most disparate Muslim intellectuals. These Muslim intellectuals understood each other very well, whether they were Tatars or Dagestanis. In addition, there was a serious participation of Muslims, of Muslim leaders, in the State Duma. They not only actively discussed, but also took part in political life. Now we see a transition to Russian, that is practically a departure from the Arabic language. Which Muslims in Russia now engage with each other in polemics or discuss Muslim issues in Arabic? That is, I am talking about the fact that this Islamic discourse has completely crossed over into Russian. And in this regard, it seems to me, a certain distance had been created from all the discussions that are happening in $\mathrm{Ar}-$ abic. Despite the fact, of course, that everything is quickly translated into Russian. All the same this very discourse is shattered. It seems to me that without analysis of the ideological searches in the Islamic intellectual community, without analysis of what is happening there, it is genuinely difficult to speak of anything and to construct any kind of theories. That is the first thing.

And the second thing. I would not focus much attention on Islamism, which all the same is more political, as it seems to me, than doctrinal. It is Islamic, naturally, but all the same it is more political. And maybe to avoid the arguments of whether it is Salafism or is it not Salafism, fundamentalism or not fundamentalism, to what extent the term fundamentalism applies or does not apply, and so on and so forth, perhaps it is worth really talking of a sort of movement toward some kind of Islamic universalism. Because all these Salafis say that there are not different Islams, that there is one Islam, and we must strive for it. This search for a universal, united Islam expresses itself both politically and in religious terminology. 
Even Shiites participate in this, because the Shiites have a movement of bringing madhhabs closer to each other. Culturally, because all the Salafi brotherhood employs consistent cultural codes, you must agree. Government authorities are driven to this. They try to identify these people by attributes.

ORKHAN Jemal: Akhmet, forgive me for interrupting. That is not a fundamental thing, but generational. Because the youth, who have spent time in the universities of Riyadh, Cairo, and Damascus, have mastered that cultural code. When you see people of my age, let's say, or even a little older, who have joined sides with the movement, even though they are from a different milieu. Well that is what happened with Muhammad Salih. This is a man from the 6os, in manner he does not differ at all from Fazil Iskander, but he is a Salafi.

Akhmet Yarlykapov: As to this universalism, I don't know, globalism -perhaps we can think in that direction. Because I again agree that these terms, fundamentalism and the like, they often mislead us in the analysis of what is happening namely with Islam and with Muslims.

Regarding the comparison of the Islamic State with Protestants, there are also many problems. There are very many problems with it, because, as it seems to me, the Islamic State is all the same evolving in the direction of developing some kind of network of absolutely new communities. They are already developing this; they well understand that they will not be allowed to flourish on the ground. And now they are very actively developing these network communities. When we speak of analyzing what is occurring in present-day Islam, it seems to me that it is very promising to analyze network activities and network communities. Because what is happening, to a large extent, goes in step with the present, in step with current technology, including the Internet.

ORKHAN JEMAL: On the whole, I completely agree, that it is a universalist, global scheme. The transition from one language to another, namely goes along the path of increasing this universality.

Irina Starodubrovskaya: I have another question about terminology. On the whole, if we could move forward in this, it would be very good, because there is absolute chaos here. But it seems to me that we cannot construct terms outside connections to "those on the 
ground." That is, if people name themselves, if they are comfortable calling themselves Salafis or fundamentalists, that needs to be taken into account. The term "fundamentalism" came to me not from academic books, but from the reality "on the ground."

DMitry Uzlaner: I have an objection exactly to this. It is a classic problem in any discipline, including the discipline of religious studies: there is the language of self-description, and there is the language of analysis. At some point we must transition from one to the other. That is, I understand that it sounds arrogant, and there is even an element of discursive violence in it. However, we cannot forever try to figure out what people call themselves. At some point we must transition to the language of analysis. And in this regard, I like what Irina is doing, because she is trying namely to transition from the languages of self-description to the language of analysis. If we, for example, consider the Christian Reformation, does it really matter much what Luther wrote about himself, how he named himself. If we use analytic method, we must understand what Reformation means. Weber describes it as a way to enter into capitalist modernity. Therefore, it seems to me that if we do not commit this discursive violence, if we do not start to devise some kind of conceptual framework, then we will finally draw in such self-descriptions. Some call themselves one thing, others call themselves another, but if we call them thus, they get offended. We will just not get anywhere.

VASily Kuznetsov: All the same a world of Islamic studies exists, in which millions of books per year are written, where there is a fully accepted language of description. There is the concept of "Salifis," there is the concept of "Islamists," there is the concept of "Jihadists." Honestly, I simply hate arguments about terminology; they often seem senseless to me. I honestly do not understand, why it is impossible to accept the existing academic, scholarly tradition. Since Islamic studies above all studies Islam, it would be logical to adopt the Islamic studies tradition and work within it.

Irina Starodubrovskaya: You know, I truly cannot find this common language. Recently I needed to figure out what is understood by Islamism in the academy, even among key researchers. I read Olivier Roy and I read Asef Bayat and they are certain that they have one and the same concept. But I started to compare and understood that they have absolutely differing concepts, different understanding of the term. 
VASily KuZNETsov: Naumkin has a thin little book called Islamic Radicalism in the Mirror of New Concepts and Approaches. In its one hundred pages, each term is discussed in detail. It is very convenient.

Emil PAIN: Akhmet and I are anthropologists and we know that in this discipline there have been a number of attempts in the last century and a half to create, if not a unified theory of the field, then a common terminology. The result has been just about as negligible as in Islamic studies. The reasons for this similarity are most likely the same - the task of developing a united concept is not realizable with admittedly lax and value-oriented approaches and definitions. In our discussion, everyone who referred to modernization gave either a different treatment of this understanding or a different enumeration of the signs of modernization. And the foundational subject of the discussion, i.e., the modernization potential of a religious phenomenon that we name fundamentalism or Salafism or Islamism, is not defined. This is not just because of the extreme complexity of this phenomenon. Even more importantly, we have different backgrounds and so the famous parable of the blind men, who feel an elephant from different sides and describe him differently, is still fair. We are different by education and by profession; we are very different (at least some of us) in our worldview, and most importantly we differ in our comprehension of the phenomena that fall within our field of vision.

I am the only open opponent of Irina here (although not in everything). I think that her conception of Islamism (fundamentalism or Salafism) as a source of modernization by analogy with the Protestant modernization can be seen as an interesting intellectual provocation, but at the same time this is a perfect utopia in practical terms. All the same, I see for myself some benefit from such interdisciplinary communication. For instance, I agree with Irina that the first contact with the "other" is a central task that arises today under the conditions of globalization on all levels: on the global, national and local levels. Therefore, the search for its solution, generally speaking, is one of the conditions for the survival of humanity. Second, it is possible and even useful to compare the "Islamic reformation" (as we call different changes in Islam, the contents of which we have not yet agreed upon) with reformations that have occurred in different religions, not just in Christianity, but also in Judaism, and many others.

If peaceful existence with cultural "others" is considered an indicator of overcoming the crisis of globalization and a manifestation of contemporary modernization, then we have the criteria for valuing 
variations of reformation, and they were always different. The evolution of Lutheranism and Calvinism, carving their way through religious wars, is one thing. Anglicanism, which was planted from above, is another thing. I have a curious example taken from the history of Judaism, which will immediately explain my position. In the 18th century in this religion, two movements arose among the European Ashkenazi Jews: one was called Haskalah, and the other Hasidism. Both movements were reformational and they could be called fundamentalism, because they refuted to a large extent the established traditional systems and appealed to some forgotten sources of Judaism. But of these two movements, only Haskalah proclaimed the ideas of liberation from the total power of the rabbinate, the rationalization of Judaism, the rejection of excessive mysticism, and a rapprochement of Jews with the local population and with Christian culture in particular. The adepts of Haskalah considered enlightenment to be their main goal, their credo. On the other hand, Hasidism preached a greater isolation in the kahal (religious community) and a greater mysticism. Several of the most radical Hasidic movements even called on the Almighty to send great calamity on the Jewish people, to force them to immerse themselves in religious spirituality and break away from worldly pleasures.

Haskalah, which at the beginning was a tiny movement formed among highly religious Jews in the cities of Germany, Austria, and a little later in Lithuania, became the dominant tendency in the Jewish world by the middle of the 19th century. It encouraged the appearance of Reform Judaism, which is even larger today than its Orthodox branch. It also inspired such personalities as Felix Mendelssohn (the great composer and grandson of the founder of the Haskalah movement, Moses Mendelssohn), Heinrich Heine, Sigmund Freud, Albert Einstein, and many others who are associated in our minds with the idea of "modernization." However, by the end of the 19th century the Haskalah movement had already lost its connection with religion and had dissolved into secular ideologies. It is now almost forgotten; only rarely is the term used in a narrow meaning, for example, to oppose more rational Reform Judaism to the more mystical Orthodox Judaism. But the other movement, Hasidism, which was originally formed in the small towns of Galicia, proclaimed the idea of isolation of the Jews and exists to this day. It is alive, but as a marginal phenomenon in the Jewish world and a deeply demodernizing movement.

There are similar variants in Islam. Vasily mentioned this, speaking of the urban euro-Islam movement, which is small in numbers and in 
some extent similar to the Jewish Haskalah. In my view, it denotes a certain likelihood of modernization through religion. At the same time, many protest movements that oppose modernization have also appeared in Islam, for example, Boko Haram. These demand from their adherents even more isolation than Hasidism does, and are significantly more aggressive in relation to the cultural "other."

Here I sum up my main theses in our discussion.

1. Many manifestations of religious reformation exist.

2. Only those forms of religious movements that either initially or at least indirectly proclaim enlightenment or modernization to be a goal can lead to modernization. In some of their manifestations they can cultivate an interest in books, education, and emancipation in their adherents. It is happening this way in some instances in the northern Caucasus, when separate movements of Salafism are used by youth for liberation from total control by the elders.

3. Historically not all religious reformations in the Christian world were the basis of modernization. The reformation of the 16th century was as deeply a contradictory sociohistorical process as many others; it enabled modernization in some aspects, but restrained it in others, at times generating fanaticism and obscurantism. Archpriest Alexander Men' noted this, explaining fanaticism, intolerance and ideological dictatorship of religious movements not by the spirit of modernization and religion, but by the deep, ancient socio-biological aspects of human nature. He also rightly noted that not just the Protestant Reformation led to modernization, but also Catholicism, in periods when its upper hierarchy supported science and enlightenment, for example when Pope Urban VIII shielded Galileo from the Inquisition.

4. The influence of religion on modernization was not identical in different times. In the Middle Ages religion absolutely dominated mass consciousness, but now it is suppressed not just by secularization, but also by a growing complexity and multiplicity of human identity. At the same time, in the era of globalization, similar changes affect representatives of all religions, therefore a complete repetition of the Christian reformation by Islamic paths is quite unlikely.

Presently religion is the least integrative form of consolidating people in the boundaries of a nation state, in comparison to ethnic and civil consolidation. If we take just the countries of the Middle East as 
an example, then we will see where there are the fewest problems for cultural "minorities," the highest indicators of population consolidation, and the relatively highest indicators of horizontal trust. Above all, it is Tunisia, which is ethnically a more homogenous country with a minimal manifestation of fundamentalism and the highest level of women's freedom. The worst conditions for the existence of cultural as well as religious "minorities" are formed where the highest manifestations of Islamic fundamentalism are found, for example in Sudan, which is one of the poorest countries in the world with many intercultural problems. Nowhere in the contemporary world does religious mobilization ensure integration within the borders of states that have retained traces of tribalism. Such pre-national communities can only hold on under rigid authoritarian power and do not demonstrate the possibility of political modernization.

Thus, there is reformation and there is reformation. As Vasily rightly noted, it is important to determine with what goal and in whose name the breaking of tradition in religion occurs. It seems to me that this idea is central for analyzing the role of fundamentalism and for predicting its consequences, because there would be no sense in limiting ourselves to the conclusion that it is all complicated and happens differently. We must find the thread that allows us to proceed to prediction.

VASILY KuZnetsov: I am pleased that we agree in some judgments; however, I must comment on your thesis about religion being the least integrative form of consolidating people in a national state. I will not undertake to confirm this thesis, nor to deny it - it is too global for me. However, regarding the Arab world, it is worth saying first that there is no need to speak of any nation-states in their classical sense. We can argue about whether we are dealing here with projects for the construction of nation-states that have not been fully completed or simply with some other forms of statehood. In the first case we will have to organize all the Arab countries according to their closeness to some imaginary ideal European model. Egypt will be closer to it and Sudan further. In the second case, it makes sense to speak simply of its effectiveness and then we need to somehow determine its criteria.

Secondly, regarding the two cited examples. As a specialist on $\mathrm{Tu}-$ nisia, I am glad to encounter any mention of it, but despite all my love for the country, I cannot agree with the thesis presented. Yes, there is a higher level of protection for women (higher than in Russia) and ethnically the population is almost homogenous. However, it is homog- 
enous also in religious confession. This means that all those wonderful things can be equally explained by both ethnic and confessional homogeneity, and the long-term policy of building a civil nation from above. However, I would not dare to speak either about an elevated level of horizontal trust, or about a high degree of public consolidation, and so on. About seven thousand fighters from Tunisia are fighting in Daesh; according to various estimates up to twelve thousand Tunisians are active in jihadist structures. The society is extremely polarized; look at the events of 2013. Pay attention to the level of racism in Tunisia; the problem is little studied but very relevant. Such things as the level of horizontal trust or the attitude toward cultural aliens are difficult to measure, and if measured, then demand colossal work with concrete data.

On the other hand, let us take Morocco and Algiers. Morocco is not ethnically homogenous but is almost homogenous by confession. It was namely the sacralization of the king that for a long time guaranteed the unity of that society, where over a third of the people are illiterate to this day. Algeria is also not ethnically homogenous. Also, it truly did not work out to consolidate this society on the basis of political Islam; everyone remembers the horrors of the 1990s. However, tribalism did not hinder implementing modernization there, even though a high degree of authoritarianism is preserved. Pay attention to the political modernization of Lebanese society. In general, it seems to me that the thesis presented is hasty.

Irina Starodubrovskaya: I want to ask a couple of questions, since, as I expected, Emil's speech was basically a discussion with me. There are several problems with saying that reformation must proclaim a modernizing, positive orientation. If we take the Protestant Reformation, about which I have personally spoken and written, then Calvin executed the inhabitants of Geneva on a massive scale. Moreover, he executed them on the basis of Old Testament moral norms as legislation. Incidentally, if you take England, then genuine reformation was Cromwell's "saints," and there it was also not very peaceful.

Orkhan Jemal: And half of the Protestant kings rose together with the Catholics against Müntzer.

Irina Starodubrovskaya: As to the question of trust, a vast number of religious wars preceded the development of the principles of re- 
ligious tolerance. The destruction of monasteries and iconoclasm led to the loss of a significant number of valuable monuments of art. Also, by the way, Hobbes wrote that in general it would have been good to kill all the Protestant preachers before they began to preach, because then it would have been possible to avoid all the losses that were connected to the English Civil War. For me, that is hardly in accords with the idea of advancing modernization as a declarative goal.

Emil Pain: I have already said that firstly not all of the history of the Protestant Reformation was modernizing, and secondly that the Islamic variant of reformation cannot be an exact replica of the Protestant one. It follows that it will not necessary repeat the terror of Calvin. If I were in power in any country, I would try, and in my place I will try, to resist similar experiments. Fortunately, I am certain that today they are very unlikely; we live in a different time.

First, in the 16th century religious identity completely dominated in a large portion of the populated territory. Now (according to data from last year's research of the Pew Research Center), in the majority of European countries where Catholicism and Protestantism historically dominated, their role had noticeably declined and the population's interest in them has weakened. It is unlikely that this tendency will not affect the adherents of other religions in these countries. According to Olivier Roy's data, today in Western Europe Islamic protestants make up less than 10 percent of Muslims.

Second, in traditionally Islamic countries Salafis, as a rule, do not make up the majority. The growth of their numbers will be complicated by the pluralization of modern identity: today most people see themselves not just as a Muslim or Christian, but simultaneously can have dozens of new identities (television viewer, football fan or member of a social network). I really hope that today humanity will not allow this type of experiment through the method of trial and error. Today the level of rationality as a whole is higher than it was during the Middle Ages or in the 19th century, and nonviolence is now normative. At least this follows from widely known documents, which if at times are declarative, still condemn violence as unacceptable.

Irina Starodubrovskaya: You need to look at Syria to see to what extent violence is not normative.

VAsily Kuznetsov: It seems to me that that the problem of the normalization of violence is outside the scope of our theme. It is largely 
connected, on the one hand, with local political culture, which is far from identical to the culture of religious confession. Compare at least Algeria with its unending hundreds of thousands of victims and $\mathrm{Tu}-$ nisia, which is historically, culturally, and geographically close, with four political assassinations in the past sixty years. On the other hand, much depends on the international environment. Yes, we have approximately 400,000 victims in Syria, up to 60,000 in Libya, and fewer in Yemen. The Syrian numbers are comparable, after amending the timeframe, to the numbers of the Iran-Iraq war and are much larger numbers than the civil war in Algeria. However, there exists a general understanding that such a level of violence is unacceptable and there also exists a substantial effort to reduce it. The fact that these efforts are ineffectual is a different issue. Besides this, in all cases, except Daesh to some extent, this violence is not undertaken in the name of realizing some political project, as it was in Nazi Germany or the Stalinist USSR. Here the question is about conflicts and the destruction of political mechanisms. This is almost always horizontal violence.

EMIL PAIN: I have not especially studied the issue of mechanisms, which do not allow experimenting with humanity. I hope such mechanisms exist or will appear. I will only note that today no one has indicated the motives that encourage a transition from bloodthirsty fanaticism to modernization, except for the rather debatable analogy with the times of medieval Europe. I have not yet lost hope that it will be a demand for renewed ideas that are in opposition to fundamentalist ones, for ideas that will be seen as prerequisites to the growth of public trust and individual freedom.

Irina STARodubrovskaya: I would very much like to hope for that. Only the objective laws of history, unfortunately, are poorly subordinated to our hopes. And they rather clearly demonstrate that for the appearance of the new, of that very modernization, about which we speak, it is necessary to clear the soil of the remains of the old. This is what Weber in his work on Protestant ethics excellently showed. Who will be ready to go against the current, to violate the established forms of life, and to question basic attitudes, creating problems for themselves and spoiling relationships with others? Probably only someone who is rigidly ideologized. A fanatic, if you wish. Not necessarily bloodthirsty, but a fanatic.

My second question is directly related to this. In reality, in the era of the Protestant Reformation there was a fully ready-made, modern- 
izing, renovationist theory. It was called the Renaissance or humanism. They advocated for personal freedom, for the elevation of the person, for individualism. It did not take off. It was not the Renaissance that became the foundation for the development of new social relations, but the Reformation. In fact, this issue remains even today, it just only changes form a little. Why? Why didn't the Renaissance become the basis for social transformation?

Emil Pain: Who said that the Renaissance did not become the basis for social transformation?

Irina Starodubrovskaya: Well Weber himself wrote that all the same it was the Reformation and not the Renaissance.

Emil Pain: I believe that it was a synthesis. The opinion is expressed in the literature that the humanism of the Renaissance served as the prerequisite for the Reformation, which called forth interest in the individual and individual responsibility. It was also the prerequisite for criticism that allowed a new look at all the phenomena of culture, including religion, and the prerequisite for the fashion for searching for ancient manuscripts that drew the attention of enlightened society to the inconsistency of the early Christian and then contemporary state of the Church. Before the Reformation became widespread, its ideas were carried by the enlightened part of society. This, without doubt, was a synthesis in historical terms and Max Weber was well aware of this. He did not infer Protestant ethics from the Reformation alone but considered changes in the economic conditions as well as the development of an urban way of life as being among the factors in the emergence of these new ethics. Weber could not simply reduce modernization, which was a much wider phenomenon than the evolution of ethics, just from the Reformation, being an apologist for rationalization and the idea of the disenchantment of the world (Entzauberung der Welt), i.e., the process of secularization and the demythologization of public life. The conception that the Reformation and Renaissance are in many ways complementary and not competing ideas is not new. It is quite widespread.

Irina Starodubrovskaya: I will state my position about why the ideas of humanism and the Renaissance all the same did not directly become the foundation for social transformation, and if anything, only partially influenced it through the Reformation. They are elitist and in 
their essence can't be the basis for protest. But the intrinsic demand was about mass ideology and the ideology of protest. And I think that these two factors continue to operate even today. Alas.

OrkHAN Jemal: Also, when we speak of the Reformation, we must understand that the Protestants had a very concrete opponent. A concrete, localized, distinct, understandable opponent, inside of which they themselves were located. That is the mother church, the Vatican, the pope. It is the exact same when we talk of Islamism. The Islamists have a very concrete opponent, inside of which Islamism is developing. It is the process that is occurring inside that very same Islamic world, the existence of which was here denied.

Irina Starodubrovskaya: Now that is very interesting! And who is the opponent? What is its name?

ORKHAN JEMAL: I think that the opponent is the world order, which at present is impossible to call Western, because it is impossible to say that it is imposed by the West. It is now holding mainly onto internal frames and not onto external dictates. I think that this world order, which implies a secular model of government, is the opponent.

Irina Starodubrovskaya: But in the Reformation the world order was also the opponent, and not just the church.

DMitry Uzlaner: If the world order had not fractured, Luther would simply have been executed and that would have been it. So many of these reformers existed who failed. A system of sovereign states was emerging.

Irina Starodubrovskaya: The memory of the execution of Hus was still present.

EMIL PAIN: The world order is generally incomprehensible, because every protest will be based exactly on that: the bad, wrong world order. Roy himself, who speaks about the tempestuous growth of Islamism in Europe, formulates it more concretely. It is the unsettled state of this world, the unadjusted state, the non-involvement. It is a way of identification in this world, where you are perceived as foreign, despite the fact that you have been living in this country for three generations. 
DMitRy Uzlaner: Allow me to make a few observations. I want to return to my thesis about the languages of self-description and the languages of analysis. I still have not had enough of this transition to the language of analysis, to an attempt of some conceptualization. All the time we are getting caught up in the concrete details. For example, when we speak of fundamentalism, after all fundamentalism is not just an understanding that exists within Islam. On the whole, from the beginning it was an understanding about Christianity, Protestantism. It indicated a specific group within Protestantism, a position of people who did not accept any kind of change. These are people who do not accept modernization, who do not accept any kind of changes, who want to live as they have lived. In principle in social theory, this position is understood as fundamentalism. There is religion, there is an encroaching modernization, there is a point of view that religion and modernization are incompatible. Accordingly, from this fundamentalism is an attempt to protect itself from modernization, to close itself off from it.

There are other positions, in particular the position that Irina is defending, that this is not fundamentalism, but an attempt, so to speak, for a creative dialogue with modernity. It is an attempt to work out some sort of path for yourself, your own solution. Indeed, if we read Weber, then it doesn't really matter what Luther said about himself, in fact this was an entry into capitalism and this entry was very successful. And if we take today's discussion: for example, Peter Berger, the sociologist. He was asked if Max Weber had died. He said that no, Max Weber is alive and well and lives in Guatemala. By this, he means that Pentecostals in Latin America are the fastest growing religious movement in history. And this is also the path for these underdeveloped people, I don't know, the poor, uneducated masses in Latin America. For them, Pentecostalism is their entry into modernity, into contemporary times, into the new spirit of capitalism. I like Irina's thesis very much, because in a way it tackles what has been said. That is, the entry of the Islamic world into modernity on its own terms and it is a very strange, paradoxical path. Such a conceptualization is possible.

I do not agree with the position that reformation necessarily must have a progressive goal. That reformation is necessarily a straight path, everything is wonderful, these are the good guys. All the same, I have studied the process of secularization. There is Charles Taylor's famous book A Secular Age, which was recently translated into Russian. It is based on the idea that secular modernity grew out of the attempt by Christians to carry out reform. People appeared who were not satisfied 
with medieval religiosity with its carnivals and its uneducated masses and peasants. They promised that they would make everyone real Christians and they began to make everyone Christian. As a result, as an unintended consequence, they achieved secularization, which is what we have today, as a matter of fact.

Besides this, one of the books that has had the greatest influence on me is Herzen's From the Other Shore, where he describes his horror at the reception of revolution in Europe. He sees some dirty, ragged people with some clubs. He is horrified that here it is, the light of history, and in this light of history stand not aristocrats in their beautiful doublets, but these half-people or half who knows what.

Irina Starodubrovskaya: And Luther with the civil war? The story is the same.

DMitry Uzlaner: That is, the mole of history, as Hegel said, he digs, and where he digs, we do not know. Therefore, I agree, indeed, that now there is a rupture of something, and what will be is unclear. Also, I like Irina's thesis in this sense, because we cannot verify or qualify it, we will only be able to do this after 400 years. But as food for thought it seems very interesting. That's what I really lacked, the attempt at this conceptualization. Maybe best of all, the processes in the Islamic world can be generalized only by someone who is not a scholar of Islam.

Irina Starodubrovsaia: And after 400 years.

DMitry UZlaner: After 400 years.

IRINA STARodubrovskaYa: If I may, as the panel chair I will say just a few words. First: I am very glad that the return to metanarratives did not call forth rejection. What I wanted to say in defense of such a presentation of the issue is that when there is a serious crisis, all the same there is a request for metanarratives. And if these metanarratives are not generated by specialists, they will be generated in other ways.

EMIL PAIN: By journalists.

Irina Starodubrovskaya: Not just by journalists. I have a feeling that it is the concept of the clash of civilizations. Huntington collected all the scary stories, all the stereotypes, all the horrors, that the av- 
erage person has, and digested them. This idea has so fully expressed the spirit of the average person's perception, that it will live and flourish completely independently of how its authors and scientists will treat it. I also have the feeling that it is important if we succeed in bringing metanarratives into this discussion.

Second. All the same, concerning the language of description, conceptualization, etc., Weber really lived 400 years later. It is simpler after 400 years. In this sense, we are compelled to be in this environment, and simultaneously, to conceptualize this environment, and simultaneously receive some kind of response from this environment. In this situation we must speak in one language. We are simply compelled to speak the same language because otherwise our conceptualization would hang in the air. After 400 years yes, I think, it will be easier. But until then, if we say Salafism, then we might somehow be understood within the Islamic community but will hardly be understood from outside. If we say universalism, then it is possible that we might somehow be understood from outside, but we will definitely not be understood from within, this will not correspond to anything. I imagine that this problem of common language from the inside and from the outside is the primary challenge. 